\title{
Weed Management in Sorghum ${ }^{1}$
}

\section{J. A. Ferrell, G. E. MacDonald, B. J. Brecke, and P. Devkota ${ }^{2}$}

Sorghum can tolerate short-term drought and is often planted towards mid-summer (in June). A late-summer sorghum may follow an early-season corn. Because sorghum is grown during a short season, weed control is essential to achieve high yields and efficient harvest. However, it is often difficult to achieve good weed control in sorghum production. This publication provides information on weed control options to the growers, pesticide applicators, and Extension personnel who must select appropriate weed control options in sorghum.

Sorghum is a small-seeded grass and is relatively slow growing in the first few weeks after emergence. In addition, sorghum is susceptible to many of the herbicides that can be effectively used on corn. Slow seedling growth combined with a limited number of labeled herbicides and low use rates create a challenge for weed control. Another problem is that many of the herbicides normally used on sorghum in other states either cannot be used or must be used at low rates due to the coarse texture of many Florida soils.

For these reasons, it is essential that practices such as choice of hybrid, soil fertility, soil $\mathrm{pH}$, moisture, and row spacing be optimized to give sorghum the best possible growing conditions in order to compete with weeds. Sorghum seeds are often treated with safener that enables the use of a specific herbicide product. Therefore, producers need to be aware of the types of safener and the herbicide product that can be applied without injuring the crop.

The most important consideration is control of grass weeds during sorghum emergence and seedling development. If grasses are not controlled at this stage and are as large as the sorghum, then cultivation will not control the grasses without killing the sorghum. Sorghum should not be planted in fields that are heavily infested with johnsongrass. If grasses can be controlled until the sorghum gets taller than the grasses, then cultivation can be effective. If sorghum is taller than the grass weeds, post-directed herbicide sprays may be applied to provide effective weed control. Broadleaf weeds are a less serious problem because several herbicides can be effectively used for their control.

Use Table 1 to determine which herbicides are most effective for anticipated weeds. Use Table 2 to determine rates and application recommendations. Proper sprayer equipment calibration and application (https://edis.ifas. ufl.edu/publication/wg013) are essential because low rates will result in poor control and high rates may result in crop injury.

1. This document is SS-AGR-06, one of a series of the Agronomy Department, UF/IFAS Extension. Original publication date January 2000. Revised November 2007, April 2012, and January 2022. Visit the EDIS website at https://edis.ifas.ufl.edu for the currently supported version of this publication.

2. J. A. Ferrell, professor, Agronomy Department; G. E. MacDonald, professor, Agronomy Department; B. J. Brecke, professor emeritus, Agronomy Department, UF/IFAS West Florida Research and Education Center, Jay, FL; and P. Devkota, assistant professor, Agronomy Department, UF/IFAS West Florida Research and Education Center, Milton, FL; UF/IFAS Extension, Gainesville, FL 32611. Original written by: J. A. Ferrell; revised by: P. Devkota.

The use of trade names in this publication is solely for the purpose of providing specific information. UF/IFAS does not guarantee or warranty the products named, and references to them in this publication do not signify our approval to the exclusion of other products of suitable composition.

All chemicals should be used in accordance with directions on the manufacturer's label.

The Institute of Food and Agricultural Sciences (IFAS) is an Equal Opportunity Institution authorized to provide research, educational information and other services only to individuals and institutions that function with non-discrimination with respect to race, creed, color, religion, age, disability, sex, sexual orientation, marital status, national origin, political opinions or affiliations. For more information on obtaining other UF/IFAS Extension publications, contact your county's UF/IFAS Extension office. U.S. Department of Agriculture, UF/IFAS Extension Service, University of Florida, IFAS, Florida A \& M University Cooperative Extension Program, and Boards of County Commissioners Cooperating. Andra Johnson, dean for UF/IFAS Extension. 
Table 1. Estimated effectiveness of herbicides on common weeds in Florida sorghum. ${ }^{1}$

\begin{tabular}{|c|c|c|c|c|c|c|c|c|c|c|}
\hline \multirow[t]{2}{*}{ WEEDS } & \multicolumn{10}{|c|}{ Herbicide } \\
\hline & $\begin{array}{l}\text { Dual or } \\
\text { Outlook }\end{array}$ & Basagran & Prowl & Atrazine & $\begin{array}{l}\text { Dicamba } \\
\text { or } 2,4-D\end{array}$ & Paraquat & Sandea & Aim & Peak & Buctril \\
\hline $\begin{array}{l}\text { Time of } \\
\text { Application }\end{array}$ & PRE & РОТ & $\begin{array}{l}\text { Culti- } \\
\text { spray }\end{array}$ & РОТ & POT/PDS & PDS & РОТ & РОТ & РОT & РОТ \\
\hline \multicolumn{11}{|c|}{ BROADLEAF } \\
\hline Bristly starbur & $\mathrm{P}$ & G & $\mathrm{P}$ & $E$ & G & G-E & G & - & - & $\mathrm{F}$ \\
\hline Cocklebur & $\mathrm{P}$ & $E$ & $\mathrm{P}$ & $\mathrm{E}$ & $E$ & $E$ & $\mathrm{E}$ & $\mathrm{F}$ & G & $E$ \\
\hline $\begin{array}{l}\text { Florida } \\
\text { beggarweed }\end{array}$ & $F-G$ & $\mathrm{~F}$ & $F-G$ & G & G & $\mathrm{G}-\mathrm{E}$ & $\mathrm{P}$ & - & - & $\mathrm{F}$ \\
\hline Florida pusley & G-E & $\mathrm{P}$ & G-E & $E$ & $\mathrm{~F}$ & $\mathrm{~F}$ & - & - & - & G \\
\hline $\begin{array}{l}\text { Morning } \\
\text { glories }\end{array}$ & $P$ & $\mathrm{~F}$ & $P$ & $E$ & $E$ & G & $\mathrm{P}$ & G & $\mathrm{F}$ & G \\
\hline Pigweed & $E$ & $\mathrm{P}$ & G & $E$ & $E$ & $\mathrm{G}-\mathrm{E}$ & G & $\mathrm{F}$ & $\mathrm{G}-\mathrm{E}$ & $\mathrm{F}$ \\
\hline Ragweed & $\mathrm{F}$ & $F-G$ & $\mathrm{~F}$ & $\mathrm{E}$ & $\mathrm{E}$ & $\mathrm{G}-\mathrm{E}$ & G & $\mathrm{F}$ & G & $\mathrm{F}$ \\
\hline Sicklepod & $\mathrm{P}$ & $\mathrm{P}$ & $P$ & $E$ & $E$ & $\mathrm{~F}$ & $\mathrm{P}$ & $\mathrm{P}$ & $F-G$ & $P$ \\
\hline \multicolumn{11}{|c|}{ GRASS } \\
\hline Crabgrass & $\mathrm{E}$ & $\mathrm{P}$ & $\mathrm{E}$ & $\mathrm{F}$ & $\mathrm{P}$ & $E$ & $\mathrm{P}$ & $\mathrm{P}$ & $\mathrm{P}$ & $\mathrm{P}$ \\
\hline Goosegrass & $E$ & $\mathrm{P}$ & $\mathrm{E}$ & $\mathrm{F}$ & $\mathrm{P}$ & $E$ & $\mathrm{P}$ & $\mathrm{P}$ & $\mathrm{P}$ & $\mathrm{P}$ \\
\hline $\begin{array}{l}\text { Johnsongrass } \\
\text { (from seed) }\end{array}$ & $\mathrm{F}$ & $\mathrm{P}$ & $\mathrm{F}$ & $\mathrm{P}$ & $\mathrm{P}$ & $\mathrm{F}$ & $\mathrm{P}$ & $\mathrm{P}$ & $\mathrm{P}$ & $P$ \\
\hline Sandbur & $E$ & $\mathrm{P}$ & $\mathrm{E}$ & G & $\mathrm{P}$ & $E$ & $\mathrm{P}$ & $\mathrm{P}$ & $\mathrm{P}$ & $\mathrm{P}$ \\
\hline Texas panicum & $\mathrm{P}$ & $\mathrm{P}$ & $\mathrm{E}$ & $F-G$ & $\mathrm{P}$ & $E$ & $\mathrm{P}$ & $\mathrm{P}$ & $\mathrm{P}$ & $\mathrm{P}$ \\
\hline \multicolumn{11}{|c|}{ SEDGE } \\
\hline $\begin{array}{l}\text { Purple } \\
\text { nutsedge }\end{array}$ & $\mathrm{P}$ & $\mathrm{P}$ & $P$ & $P$ & $\mathrm{P}$ & $F-G$ & G-E & $\mathrm{P}$ & $\mathrm{P}$ & $P$ \\
\hline $\begin{array}{l}\text { Yellow } \\
\text { nutsedge }\end{array}$ & $\mathrm{F}$ & G & $\mathrm{F}$ & $P$ & $\mathrm{P}$ & $F-G$ & G & $\mathrm{P}$ & $\mathrm{P}$ & $P$ \\
\hline \multicolumn{11}{|c|}{$\begin{array}{l}\text { 'Estimated effectiveness based on herbicide rates recommended in this report. Effectiveness may vary depending on factors such as herbicide, size of weeds, } \\
\text { time of application, soil type, and weather conditions. }\end{array}$} \\
\hline \multicolumn{11}{|c|}{$\begin{array}{l}\text { Time of Application } \\
\text { PRE = Preemergence } \\
\text { POT = Postemergence broadcast } \\
\text { PDS = Directed postemergence }\end{array}$} \\
\hline \multicolumn{11}{|c|}{$\begin{array}{l}\text { Weed Control Symbols } \\
E=90-100 \% \text { control } \\
G=80-90 \% \text { control } \\
F=60-80 \% \text { control } \\
P=\text { Less than } 60 \% \text { control }\end{array}$} \\
\hline
\end{tabular}


Table 2. Weed management in sorghum. Contact: UF/IFAS Extension weed specialist (pdevkota@ufl.edu). This table lists registered pesticides that should be integrated with other weed management methods. Contact your local UF/IFAS Extension office for additional information (https://ifas.ufl.edu/maps/).

\begin{tabular}{|c|c|c|c|c|}
\hline $\begin{array}{l}\text { Herbicide Active } \\
\text { Ingredient (Trade/ } \\
\text { Product Names) }\end{array}$ & $\begin{array}{l}\text { Mode of Action } \\
\text { Group (MoA) }\end{array}$ & $\begin{array}{l}\text { Application Rate } \\
\text { per Acre }\end{array}$ & $\begin{array}{l}\text { Reentry Interval } \\
\text { (REI) }\end{array}$ & Specific Comments/Remarks \\
\hline \multicolumn{5}{|c|}{ PREEMERGENCE } \\
\hline $\begin{array}{l}\text { S-metolachlor }{ }^{1} \text { (Dual } \\
\text { Magnum, Dual II } \\
\text { Magnum) }\end{array}$ & 15 & $1.0-1.33 \mathrm{pt}$ & $24 \mathrm{hrs}$ & $\begin{array}{l}\text { Use on seed that has been treated with a chemical } \\
\text { safener such as Concep. If seed is not properly } \\
\text { treated, severe injury will occur. S-metolachlor } \\
\text { provides good control of many grasses and certain } \\
\text { small-seeded broadleaf weeds. Apply after planting } \\
\text { but before weeds and sorghum emerge. It can also } \\
\text { be applied with liquid fertilizer. }{ }^{2}\end{array}$ \\
\hline $\begin{array}{l}\text { Metolachlor (Stalwart, } \\
\text { Parallel, others) }\end{array}$ & 15 & $1-1.3 \mathrm{pt}$ & $24 \mathrm{hrs}$ & $\begin{array}{l}\text { See above. Note that metolachlor products will } \\
\text { commonly provide less soil residual control than } \\
\text { those containing S-metolachlor. }\end{array}$ \\
\hline $\begin{array}{l}\text { Dimethenamid-p } \\
\text { (Outlook, others) }\end{array}$ & 15 & $13 \mathrm{oz}$ & $12 \mathrm{hrs}$ & $\begin{array}{l}\text { Similar to S-metolachlor. Less effective on tropical } \\
\text { spiderwort. }\end{array}$ \\
\hline \multicolumn{5}{|c|}{ POSTEMERGENCE } \\
\hline $\begin{array}{l}\text { Atrazine } \\
\text { (AAtrex or Atrazine }{ }^{3} \text { ) } \\
\text { (several formulations) }\end{array}$ & 5 & $1-2 \mathrm{lb}$ ai/A & $12 \mathrm{hrs}$ & $\begin{array}{l}\text { Apply after sorghum reaches the } 3 \text {-leaf stage and } \\
\text { before broadleaf weeds are } 4 \text { inches tall. For ground } \\
\text { applications, add emulsifiable oil concentrate at } 1 \\
\text { qt/A. Do not apply more than } 2 \mathrm{lb} \text { per application } \\
\text { and do not apply more than } 2.5 \mathrm{lb} / \mathrm{A} / \text { season or year. } \\
\text { Do not graze or feed forage for } 21 \text { days following } \\
\text { application. A restricted-use pesticide. }\end{array}$ \\
\hline $\begin{array}{l}\text { Carfentrazone } \\
\text { (Aim 2EC) }\end{array}$ & 14 & $0.5-1 \mathrm{fl} \mathrm{oz}$ & $12 \mathrm{hrs}$ & $\begin{array}{l}\text { Can be applied to sorghum beginning } 30 \text { days prior } \\
\text { to planting until the } 6 \text {-leaf collar growth stage. } \\
\text { Controls many broadleaf weeds, but good coverage } \\
\text { is essential. Addition of nonionic surfactant ( } 0.25 \% \\
\mathrm{v} / \mathrm{v} \text { ) is required. Crop oil is not recommended due } \\
\text { to increased crop injury. Directed applications are } \\
\text { recommended if rates higher than } 0.5 \text { oz are used. } \\
\text { Expect moderate leaf burning from over-the-top } \\
\text { applications. Do not apply to sweet sorghum. }\end{array}$ \\
\hline $\begin{array}{l}\text { 2,4-D amine or ester }{ }^{2,4} \\
\text { (several brands) }\end{array}$ & 4 & $0.5-1 \mathrm{pt}$ & $48 \mathrm{hrs}$ & $\begin{array}{l}\text { Controls broadleaf weeds. Sorghum is not as } \\
\text { tolerant to } 2,4-D \text { as corn. Broadcast after sorghum } \\
\text { is } 6-8 \text { inches tall. If sorghum is } 10-15 \text { inches, use } \\
\text { drop nozzles to direct spray toward base of plant. } \\
\text { Over-the-top applications are most likely to result in } \\
\text { herbicide injury. Do not treat sorghum in boot, tassel, } \\
\text { or soft dough stage. Avoid drift to other sensitive } \\
\text { crops at nearby location. }\end{array}$ \\
\hline $\begin{array}{l}\text { Dicamba } \\
\text { (Banvel, Clarity, Sterling }{ }^{4} \text { ) }\end{array}$ & 4 & $0.5 \mathrm{pt}$ & $24 \mathrm{hrs}$ & $\begin{array}{l}\text { Broadleaf weeds controlled. Apply from the } 3 \text {-leaf } \\
\text { stage until plant reaches } 8 \text { inches tall. Apply only as } \\
\text { a directed spray on plants that are between } 8 \text { and } 15 \\
\text { inches. Do not graze or feed treated sorghum, forage, } \\
\text { or silage prior to mature grain stage. Avoid drift to } \\
\text { other sensitive crops. }\end{array}$ \\
\hline $\begin{array}{l}\text { Bentazon } \\
\text { (Basagran) }\end{array}$ & 6 & $1.5-2.0 \mathrm{pt}$ & $48 \mathrm{hrs}$ & $\begin{array}{l}\text { Apply over the top before weeds exceed } 4-6 \text { inches } \\
\text { in height. Grain sorghum should be fully emerged. } \\
\text { Sorghum is very tolerant to bentazon, but do not } \\
\text { apply to sorghum that is heading or blooming. Apply } \\
\text { with a crop oil adjuvant at a rate of } 1 \text { qt/A. }\end{array}$ \\
\hline $\begin{array}{l}\text { Bromoxynil } \\
\text { (Buctril 2EC) }\end{array}$ & 6 & $1-1.5 \mathrm{pt}$ & $24 \mathrm{hrs}$ & $\begin{array}{l}\text { Apply to sorghum between the 3-leaf stage to } \\
12 \text {-inch height or pre-boot stage to control most } \\
\text { broadleaf weeds in the } 2 \text { - to } 4 \text {-leaf stage of growth. } \\
\text { Use } 10 \text { or more gallons of water per acre. }\end{array}$ \\
\hline
\end{tabular}




\begin{tabular}{|c|c|c|c|c|}
\hline $\begin{array}{l}\text { Herbicide Active } \\
\text { Ingredient (Trade/ } \\
\text { Product Names) }\end{array}$ & $\begin{array}{c}\text { Mode of Action } \\
\text { Group (MoA) }\end{array}$ & $\begin{array}{l}\text { Application Rate } \\
\text { per Acre }\end{array}$ & $\begin{array}{l}\text { Reentry Interval } \\
\text { (REI) }\end{array}$ & Specific Comments/Remarks \\
\hline $\begin{array}{l}\text { Linuron } \\
\text { (Lorox 4L) }\end{array}$ & 7 & $1-2 \mathrm{pt}$ & $24 \mathrm{hrs}$ & $\begin{array}{l}\text { Apply as a directed spray after sorghum is } 12 \text { inches } \\
\text { tall. Use low rate when sorghum is } 12-15 \text { inches tall, } \\
\text { and a sprayer equipped with skids, shoes, or shields. } \\
\text { Use the high rate when sorghum is taller than } 15 \\
\text { inches and weeds are up to } 4 \text { inches in height. Make } \\
\text { only one application per season. Add nonionic } \\
\text { surfactant ( } 1 \text { pt/ } 25 \text { gal spray). DO NOT graze or } \\
\text { feed plant parts to livestock within } 3 \text { months after } \\
\text { application. }\end{array}$ \\
\hline $\begin{array}{l}\text { Paraquat } \\
\text { (Gramoxone SL) } \\
\text { Or } \\
\text { (Firestorm, Parazone, } \\
\text { others) }\end{array}$ & 22 & $\begin{array}{c}1-2 \mathrm{pt} \\
\text { Or } \\
0.7-1.3 \mathrm{pt}\end{array}$ & $12 \mathrm{hrs}$ & $\begin{array}{l}\text { Paraquat controls grass and broadleaf weeds. Apply } \\
\text { as a directed spray when sorghum is a minimum } \\
\text { of } 12 \text { inches tall and weeds are under } 3 \text { inches tall. } \\
\text { Use precision directed-spray application equipment } \\
\text { adjusted so that no more than the lower } 3 \text { inches of } \\
\text { the sorghum stalk are contacted by the herbicide } \\
\text { spray. Add nonionic surfactant at } 1 \text { qt per } 100 \text { gal of } \\
\text { spray. }\end{array}$ \\
\hline $\begin{array}{l}\text { Prosulfuron } \\
\text { (Peak 57DF) }\end{array}$ & 2 & $0.75-1.0 \mathrm{oz}$ & $12 \mathrm{hrs}$ & $\begin{array}{l}\text { Provides postemergence and residual control of } \\
\text { many annual broadleaf weeds. Apply after sorghum } \\
\text { reaches } 5 \text { inches in height and before it reaches } 30 \\
\text { inches. Refer to the label for specific weed sizes; } \\
\text { as a general rule, apply before weeds exceed 4-6 } \\
\text { inches in height. The use of a nonionic surfactant or } \\
\text { crop oil is recommended. May be tank-mixed with } \\
\text { Banvel, 2,4-D, or atrazine. Do not apply Peak within } \\
15 \text { days to sorghum treated with foliar-applied } \\
\text { organophosphate insecticides. Do not graze within } \\
30 \text { days of application or harvest silage within } 40 \\
\text { days of application. Do not apply to sweet sorghum. } \\
\text { Rotational restrictions include the following: wheat, } \\
\text { barley, rye, oats-0 months; field corn-1 month; } \\
\text { peanuts, tobacco, cotton-10 months. }\end{array}$ \\
\hline $\begin{array}{l}\text { Halosulfuron } \\
\text { (Sandea) }\end{array}$ & 2 & $2 / 3-1$ oz & $12 \mathrm{hrs}$ & $\begin{array}{l}\text { May be applied from the 2-leaf stage through layby } \\
\text { (before head emergence) to control nutsedge and } \\
\text { other broadleaf weeds. Do not apply more than } 1 \\
\text { oz/A/yr. Applications to a stressed crop will increase } \\
\text { injury for 7-10 days. }\end{array}$ \\
\hline $\begin{array}{l}\text { Pendimethalin } \\
\text { (Prowl } \mathrm{H}_{2} \mathrm{O} \text { ) } \\
\text { (culti-spray) }\end{array}$ & 3 & $1.5 \mathrm{pt}$ & $24 \mathrm{hrs}$ & $\begin{array}{l}\text { For extended control of late-season grasses, } \\
\text { cultivate so that brace roots and stems are covered } \\
\text { and protected when sorghum is } 4 \text { inches tall or in } \\
\text { the } 2 \text {-leaf stage. Immediately spray with Prowl. If } \\
\text { rainfall ( } 0.5 \text { inches) is not received within } 7 \text { days after } \\
\text { application, incorporate with a sweep-type or rolling } \\
\text { cultivator. Can be tank-mixed with atrazine. }\end{array}$ \\
\hline
\end{tabular}




\begin{tabular}{|c|c|c|c|c|}
\hline $\begin{array}{l}\text { Herbicide Active } \\
\text { Ingredient (Trade/ } \\
\text { Product Names) }\end{array}$ & $\begin{array}{l}\text { Mode of Action } \\
\text { Group (MoA) }\end{array}$ & $\begin{array}{l}\text { Application Rate } \\
\text { per Acre }\end{array}$ & $\begin{array}{l}\text { Reentry Interval } \\
\text { (REI) }\end{array}$ & Specific Comments/Remarks \\
\hline $\begin{array}{l}\text { Nicosulfuron } \\
\text { Zest WDG }\end{array}$ & 2 & $0.67-1.33 \mathrm{oz}$ & $4 \mathrm{hrs}$ & $\begin{array}{l}\text { Useonly on GRAIN SORGHUM VARIETIES containing } \\
\text { The Dupont (Corteva) INZEN HERBICIDE TOLERANT } \\
\text { TRAIT. Can be broadcast applied from emergence } \\
\text { up to } 20 \text { inches tall. Optimum crop tolerance when } \\
\text { applied to } 4 \text { - to } 20 \text {-inch grain sorghum. Do not apply } \\
\text { to grain sorghum taller than } 20 \text { inches. Maximum of } \\
1.8 \text { oz/A of ZEST can be applied per season or year. } \\
\text { Add surfactant (a nonionic surfactant at } 1 \mathrm{qt} \text {; or crop } \\
\text { oil concentrate at } 1 \text { gal per } 100 \text { gal of spray solution). } \\
\text { Use } 2 \text { qt/A of } 28 \% \text { Nor } 32 \% \text { urea ammonium } \\
\text { nitrate (UAN), or } 2 \text { lb/A of ammonium sulfate (AMS). } \\
\text { Read and follow the label for tank-mix options. Zest } \\
\text { WDG has a long Rotational Interval for some crops; } \\
\text { refer to Rotational Crop Guideline on the label before } \\
\text { applying this herbicide. }\end{array}$ \\
\hline \multicolumn{5}{|c|}{$\begin{array}{l}{ }^{1} \text { Concep III, manufactured by Syngenta Corp., is a seed protectant applied to sorghum seed to minimize injury when the herbicides Dual Magnum or Dual II } \\
\text { Magnum are used on sorghum for weed control. Screen, manufactured by Monsanto Company, is a seed protectant applied to sorghum seed to minimize injury } \\
\text { when the herbicides Dual Magnum or Dual II Magnum are used on sorghum for weed control. }\end{array}$} \\
\hline \multicolumn{5}{|c|}{$\begin{array}{l}{ }^{2} \text { Observations in wheat fields indicate crop damage when 2,4-D is tank-mixed with liquid nitrogen. This also may be evident with other herbicide-nitrogen } \\
\text { mixtures. To avoid possible damage and obtain better weed control, herbicides and nitrogen should be applied separately. }\end{array}$} \\
\hline \multicolumn{5}{|c|}{$\begin{array}{l}{ }^{3} \text { WARNING: THE FOLLOWING STATEMENT HAS BEEN ADDED TO THE ATRAZINE LABEL. THIS STATEMENT SHOULD BE HEEDED BY ALL PROSPECTIVE USERS AND } \\
\text { STEPS SHOULD BE TAKEN TO COMPLY WITH THIS LABEL CHANGE. } \\
\text { ATRAZINE IS A CHEMICAL WHICH CAN TRAVEL (SEEP OR LEACH) THROUGH SOIL AND CAN CONTAMINATE GROUNDWATER AS A RESULT OF AGRICULTURAL USE. } \\
\text { ATRAZINE HAS BEEN FOUND IN GROUNDWATER AS A RESULT OF AGRICULTURAL USE. USERS ARE ADVISED NOT TO APPLY ATRAZINE WHERE THE WATER TABLE } \\
\text { (GROUNDWATER) IS CLOSE TO THE SURFACE AND WHERE THE SOILS ARE VERY PERMEABLE, i.e., WELL-DRAINED SOILS SUCH AS LOAMY SANDS. YOUR LOCAL } \\
\text { AGRICULTURAL AGENCIES CAN PROVIDE FURTHER INFORMATION ON THE TYPE OF SOIL IN YOUR AREA AND THE LOCATION OF GROUNDWATER. IN ADDITION, } \\
\text { SOME PRODUCT LABEL STATEMENTS INCLUDE AS A FURTHER QUALIFICATION OF RISKY SOILS, SOILS CONTAINING SINKHOLES OVER LIMESTONE BEDROCK, } \\
\text { SEVERELY FRACTURED SURFACES, AND SUBSTRATES WHICH WOULD ALLOW DIRECT INTRODUCTION INTO AN AQUIFER. }\end{array}$} \\
\hline \multicolumn{5}{|c|}{$\begin{array}{l}{ }^{4} \text { See fact sheet SS-AGR-12, Florida's Organo-Auxin Herbicide Rule, for state rules pertaining to application of organo-auxin herbicides in Florida. } \\
\text { Herbicide recommendations in this report are contingent upon their registration by the Environmental Protection Agency. If a registration is canceled, the } \\
\text { herbicide would no longer be recommended. }\end{array}$} \\
\hline
\end{tabular}

